\title{
Hypothyroidism and pregnancy. Situation in Latvia
}

\author{
Anna Abramova ${ }^{1}$, Ramona Galsone ${ }^{2}$ \\ ${ }^{1}$ Department of Medicine, Rigas Stradins University, Riga, Latvia \\ ${ }^{2}$ Department of Medicine, University of Latvia, Riga, Latvia \\ Received: 21 April 2015 \\ Revised: 06 May 2015 \\ Accepted: 09 May 2015

\section{*Correspondence:} \\ Dr. Anna Abramova, \\ E-mail: abramova.anna.4@gmail.com \\ Copyright: () the author(s), publisher and licensee Medip Academy. This is an open-access article distributed under \\ the terms of the Creative Commons Attribution Non-Commercial License, which permits unrestricted non-commercial \\ use, distribution, and reproduction in any medium, provided the original work is properly cited.
}

\begin{abstract}
The thyroid gland is the first of the body's endocrine glands to develop, on approximately the $24^{\text {th }}$ day or $3-4$ weeks of gestation, but at around 10-12 weeks the thyroid begins to function on its own. Thyroid hormones are involved in regulation of vital body function. In general normal development, growth and reproduction cannot occur without them. The normal function of thyroid gland is predictor to normal pregnancy outcome and foetus development. It is important to know how many women have hypothyroidism and what kind of treatment they receive. Author selected and made retrospective analysis of women with hypothyroidism maternity cases from 2010 to 2011 year. Data compared to the control group, which includes women without hypothyroidism. 160 histories of childbirth of pregnant women with hypothyroidism were summarised and included into hypothyroidism group and 308 histories of childbirth in control group. Preeclampsia incidence in hypothyroidism group is $6.9 \%$, and $2.6 \%$ in the control group. The incidence of preeclampsia statistically differs in both study groups. $(\mathrm{P}=0.02642)$. Results of the study show that hypothyroidism does not affect the delivery type. Only $8.5 \%$ of patients in hypothyroidism group weren't receiving Lthyroxin therapy during pregnancy. Women with hypothyroidism have preeclampsia more often than women which hasn't hypothyroidism. Hypothyroidism does not affect the delivery type.
\end{abstract}

Keywords: Hypothyroidism, Pregnancy, Latvia, Thyroid gland, L-thyroxin

\section{INTRODUCTION}

\section{Thyroid gland anatomy and embryology}

The primary event in the phylogeny of the thyroid was the development in living forms of the capability of collecting iodide ion and binding it to protein. These activities have been observed widely among plants and in the invertebrate members of the animal kingdom. ${ }^{1}$

The thyroid gland develops from an endodermal thickening of cells that originate from the third branchial pouch. Some cells originate from the fourth branchial pouch. During development, the thyroid is actually located in the back of the tongue, to a point known as the foramen caecum and has to migrate to the front of the neck before birth, and after birth located anteriorly in the neck. $^{2,3}$ The thyroid originates from two main structures: the primitive pharynx and the neural crest. The rudimentary lateral thyroid develops from neural crest cells, while the median thyroid, which forms the bulk of the gland, arises from the primitive pharynx. The thyroid gland is the first of the body's endocrine glands to develop, on approximately the 24th day or 3-4 weeks of gestation, but at around 10-12 weeks the thyroid begins to function on its own. ${ }^{4-7}$ The gland consists of two elongated lateral lobes (left and right) connected by a thin, median isthmus overlying the second to fourth tracheal rings, typically forming an " $\mathrm{H}$ " or " $U$ " shape. The lateral lobes and median isthmus fuse when the embryo is $13 \mathrm{~mm}$ long. ${ }^{5}$ Lateral lobes can be likened to a butterfly. Occasionally the isthmus is absent and the 
thyroid exists as two distinct lobes, each lobe is 50-60 mm long. Almost always thyroid lobes are asymmetrical with the right lobe larger than the left lobe. Thyroid gland weight is from $20 \mathrm{~g}$ to $30 \mathrm{~g} .{ }^{8,9}$ Thyroid gland is a highly vascularized. The blood flow has been estimated to be approximately $5 \mathrm{ml} /$ gram of tissue, which is almost twice as rich as that of the kidney. It receives its blood supply from the superior and inferior thyroid arteries and extending from the fifth cervical to the first thoracic vertebrae. In some cases is the one more artery which calls thyroidea ima artery or thyroid artery of Neubauer. The thyroidea ima artery is an uncommon variant of the blood supply to the inferior aspect of the thyroid gland. It is reported in $\sim 7.5 \%$. $^{5}$ There are three main veins that drain the venous plexus on the anterior surface of the thyroid, superior, middle, and inferior thyroid veins. Superior and middle thyroid veins drains into the internal jugular vein, but inferior thyroid vein drains into the left brachiocephalic vein. Thyroid gland has innervation from sympathetic and parasympathetic nerves. Parasympathetic fibers come from the nervus vagus, and sympathetic fibers are from the superior, middle, and inferior ganglia of the sympathetic trunk. ${ }^{9,10}$

\section{WHAT DOES THE THYROID GLAND DO?}

The thyroid gland has an inner capsule, which is thin and adheres closely to the gland. Extensions of this capsule form numerous septae, which divide thyroid gland into many lobes and lobules. ${ }^{10}$ The lobules are composed of follicles. The follicles are the functional units of the gland in which thyroid hormone is synthesized and stored. Each follicle consists of a single layer of epithelial cells or follicular cells or thyrocytes. The follicular cells are produced the thyroid hormones $\mathrm{T}_{3}$ or triiodothyronine and $\mathrm{T}_{4}$ or tetraiodothyroninene, also called thyroxine. The $\mathrm{T}_{3}$ is more biologically active than $\mathrm{T}_{4}$. The follicular cells also resting on a basement membrane and secluding an inner follicular cavity, the lumen, which serves as the actual production place of thyroid hormones and storage after their synthesis. Calcitonin producing C-cells located between the follicles in a so-called parafollicular cells. $^{3,5,10}$

\section{THE SYNTHESIS OF $\mathrm{T}_{3}$ AND $\mathrm{T}_{4}$}

The synthesis of thyroid hormones is dependent on iodine from the diet. Ingested iodine is absorbed through the small intestine. The thyrocytes concentrate iodine in the form of the iodide using an iodine trap or sodium-iodide symporter. The iodine trap actively pumps iodide from the blood circulation into the follicles. In the thyroid gland iodine is concentrated, oxidized, and then incorporated into thyroglobulin to form $\mathrm{T}_{4}$ and $\mathrm{T}_{3}{ }^{3,11}$ Thyroperoxidase is an enzyme involved in thyroid hormone synthesis, catalysing the oxidation of iodide on tyrosine. ${ }^{10}$ The synthesis of thyroid hormone is regulated by thyroid stimulating hormone from the anterior pituitary gland by a negative feedback mechanism. The release of thyroid stimulating hormone is modulated by thyrotropin-releasing hormone produced by the hypothalamus. $^{3}$ The normal thyroid maintains a concentration of free iodide 20 to 50 times higher than that of plasma, depending on the amount of available iodine and the activity of the gland. ${ }^{10}$ Iodine is an indispensable component of the thyroid hormones, comprising $65 \%$ of $\mathrm{T}_{4}$ weight, and $58 \%$ of $\mathrm{T}_{3}$. The thyroid hormones are the only iodine-containing compounds with established physiologic significance in humans. After metabolic effect iodide is reused or excreted in kidney. ${ }^{11}$

\section{THYROID GLAND FUNCTION}

Thyroid hormones are involved in regulation of vital body function. In general normal development, growth and reproduction cannot occur without them. Without the presence of thyroid hormones full effect of many other hormones cannot be realised. Growth can be an increase in cell size or an increase in the number of cells. ${ }^{3,12}$

\section{THYROID GLAND AND PREGNANCY}

Two pregnancy-related hormones: human chorionic gonadotropin and estrogen cause increased thyroid hormone levels in the blood. Made by the placenta, human chorionic gonadotropin is similar to thyroid stimulating hormone and mildly stimulates the thyroid to produce more $\mathrm{T}_{3}$ and $\mathrm{T}_{4}$ (Table 2 ). Increased estrogen produces higher levels of thyroid-binding globulin that transports thyroid hormone in the blood. ${ }^{6}$ The thyroid gland can increase in size during pregnancy. This is usually only a 10-15\% increase in size and is not apparent on physical examination by the physician.

Thyroid problems can be difficult to diagnose in pregnancy due to higher levels of thyroid hormone in the blood, increased thyroid size, fatigue, \& other symptoms common to both pregnancy and thyroid disorders. ${ }^{6}$

\section{HYPOTHYROIDISM AND PREGNANCY OUTCOMES}

In women in the reproductive age autoimmune thyroid disease or Hashimoto's disease is the most common cause of hypothyroidism. Hashimoto's disease is a form of chronic inflammation of the thyroid gland. ${ }^{6,14}$ Hypothyroidism is estimated to occur in $0.3-0.5 \%$ of pregnancies, but subclinical hypothyroidism appears to occur 2-3\% of pregnancies. Hypothyroidism can cause menstrual disorders and infertility. ${ }^{15}$

Recommendations for TSH levels during pregnancy are the following: first trimester, 0.1-2.5 mIU/L; second trimester, 0.2-3.0 mIU/L; third trimester, 0.3-3.0 mIU/L. If the TSH is greater than 2.5 at any time during pregnancy, $\mathrm{T}_{4}$ levels should be checked to determine whether the hypothyroidism is overt or subclinical. If $\mathrm{T}_{4}$ is low, the diagnosis is overt hypothyroidism. If TSH is high and the $\mathrm{T}_{4}$ is normal, the diagnosis is subclinical hypothyroidism. ${ }^{15,16}$ 
Table 1: Thyroid hormone effects in the humans body. $3,13,15-18,30-33$

\begin{tabular}{|c|c|}
\hline Function & Effect \\
\hline Basal metabolic rate & $\begin{array}{l}\text { Increase the basal metabolic rate of almost all the cells in the body. } \\
\text { High levels of iodothyronines can cause a slight increase in body temperature and a decrease in } \\
\text { heat tolerance. } \\
\text { Low levels of iodothyronines can cause a decrease in basal metabolic rate and a decreased } \\
\text { tolerance to the cold. }\end{array}$ \\
\hline Fat metabolism & $\begin{array}{l}\text { Increase lipolysis. } \\
\text { High levels of } \mathrm{T}_{3} \text { and } \mathrm{T}_{4} \text { will result in a fall in body weight. } \\
\text { Low levels of } \mathrm{T}_{3} \text { and } \mathrm{T}_{4} \text { will result in increased blood cholesterol concentration. }\end{array}$ \\
\hline Carbohydrate metabolism & $\begin{array}{l}\text { Thyroid hormones stimulate almost all aspects of carbohydrate metabolism, including enhancement } \\
\text { of insulin-dependent entry of glucose into cells and increased gluconeogenesis and glycogenolysis } \\
\text { to generate free glucose. }\end{array}$ \\
\hline Protein metabolism & $\begin{array}{l}\text { Iodothyronines stimulate both protein synthesis and degradation. High levels of } \mathrm{T}_{3} \text { and } \mathrm{T}_{4} \text { will } \\
\text { result in a fall in muscle mass and body weight. } \\
\text { Thyroid hormone excess induces cardiac hypertrophy } \\
\text { Iodothyronines play an important role in normal growth and development. }\end{array}$ \\
\hline Cardiovascular system & $\begin{array}{l}\text { The iodothyronines have a direct effect on the heart by potentiating the catecholamine. Palpitation } \\
\text { is one of the most-common symptoms associated with overt hyperthyroidism. } \\
\text { Thyroid hormones also promote vasodilation, which leads to enhanced blood flow to many organs. }\end{array}$ \\
\hline Skeletal system & $\begin{array}{l}\text { High levels of } \mathrm{T}_{3} \text { and } \mathrm{T}_{4} \text { are associated with increased bone turnover. } \\
\text { Hypothyroidism and hyperthyroidism are both associated with an increased risk of fracture. } \\
\text { Bone cells are stimulated to both increase bone resorption and bone synthesis. }\end{array}$ \\
\hline Reproductive system & $\begin{array}{l}\text { Thyroid disorders can cause abnormally early or late onset of puberty and menstruation. } \\
\text { Decreased function of thyroid gland can lead a menstrual disorders - menstrual cycle irregularities, } \\
\text { ranging from absent or infrequent periods to very frequent and heavy periods. } \\
\text { Thyroid disorders may cause the early onset of menopause. }\end{array}$ \\
\hline Central nervous system & $\begin{array}{l}\text { The effects of the iodothyronines on the central nervous system are thought to be due to the } \\
\text { potentiation of their catecholamine activity. } \\
\text { Hypothyroidism or hyperthyroidism can lead to mood disorders, dementia, confusion, and } \\
\text { personality changes. } \\
\text { Thyroid hormone deficiency, even of short duration may lead to irreversible brain damage. }\end{array}$ \\
\hline
\end{tabular}

Table 2: Thyroid hormones during pregnancy.

\begin{tabular}{|llll|} 
TSH & $\begin{array}{l}1^{\text {st }} \text { trimester } \\
\text { decreased }\end{array}$ & $2^{\text {nd }}$ trimester & $3^{\text {rd }}$ trimester \\
\hline Free $\mathrm{T}_{4}$ & Normal & Normal & Normal \\
\hline Free $\mathrm{T}_{3}$ & Normal & Normal & Normal \\
\hline Total $\mathrm{T}_{4}$ & High & High & High \\
\hline Total $\mathrm{T}_{3}$ & High & High & High \\
\hline
\end{tabular}

The adverse outcomes of uncontrolled hypothyroidism during pregnancy include:

\section{- Anaemia;}

- Preeclampsia;

- Increased risk of miscarriage;

- Placental abruption;

- $\quad$ Premature birth;
- Congestive heart failure;

- $\quad$ Stillbirth;

- Low birth weight;

- Myopathy;

- Postpartum haemorrhage;

- Impaired neuropsychological development of the baby. $6,7,17$

Decrease level of thyroid hormone, even of short duration may lead to irreversible brain damage. ${ }^{18} \mathrm{~T}_{3}$ and $\mathrm{T}_{4}$ regulate the processes of terminal brain differentiation: dendritic and axonal growth, synaptogenesis, neuronal migration and myelination. ${ }^{19}$ Thyroid hormone exerts important influences on cell migration in the cerebral cortex, hippocampus and cerebellum. Neuronal migration in the cerebral cortex is extremely sensitive to thyroid hormones, and even minor deficiencies are associated 
with migration defects. In the cerebellum thyroid hormones are involved in the late phase of granular cell migration from the external germinal layer to the internal granular layer. Hypothyroidism causes delayed and poor deposition of myelin whereas hyperthyroidism accelerates myelination. ${ }^{18}$

The thyroid status of neonates and children has a significant long-term impact on their behaviour, locomotors ability, speech, hearing and cognition, lower IQs later in childhood. Deficiency of thyroid hormones in children results in retarded skeletal development, delayed bone age, growth arrest because of epiphyseal disgenesia. Observational studies performed in iodine-deficient parts of the world have shown that iodine supplementation before pregnancy and in the first and second trimesters reduces the incidence of cretinism but supplementation beginning later in pregnancy does not improve the neurodevelopmental status of the offspring. Mothers who stopped smoking during pregnancy their thyroid hormone levels were comparable to levels found in non-smokers, which suggests that changes in thyroid function are rapidly reversible, and doctor should ask mother to stop smoking. ${ }^{17,19,20}$

Before pregnancy, during pregnancy and at the breast feeding time woman needs $150-250 \mu \mathrm{g} / \mathrm{per}$ day of potassium iodine. Seafood is naturally rich in iodine. Cod, sea bass, haddock, and perch are good sources. Kelp is the most common vegetable-seafood that is a rich source of iodine. If a daily diet including 75 grams of salmon, 100 grams of flounder, cod 165 grams, 270 grams of golden perch or 250 grams of kelp (from 200 to $4500 \mathrm{mcg}$ ) a person will get the required quantity of iodine. $^{21}$

During the pregnancy women need more potassium iodine because:

- $\mathrm{T}_{4}$ synthesis during pregnancy is higher;

- $\mathrm{T}_{4}$ and potassium iodine transportation to foetus;

- Iodine excretion in urine increases. ${ }^{16}$

If woman has hypothyroidism she should have her levothyroxine dose optimized before pregnancy. Women with known hypothyroidism should have their thyroid function tested as soon as pregnancy is detected. The levothyroxine dose needed to maintain a TSH in the normal range. Thyroid function tests should be checked approximately every 6-8 weeks during pregnancy to ensure that the woman has normal thyroid function throughout pregnancy. ${ }^{7,15}$

Some physician groups recommend checking a woman's TSH value either before becoming pregnant or as soon as pregnancy is confirmed. Women with:
- History of thyroid dysfunction and/or thyroid surgery, miscarriage, preterm delivery, infertility, head or neck irradiation;

- Family history of thyroid disease;

- Goitre;

- Thyroid antibodies;

- Symptoms of hypothyroidism. It is important to note that women with overt hypothyroidism are not invariably symptomatic;

- Type I diabetes, in whom the rate of development of new onset hypothyroidism in pregnancy was $16 \%$ in one series;

- Autoimmune disorders that are frequently associated with autoimmune thyroid dysfunction, including vitiligo, adrenal insufficiency, hypoparathyroidism, atrophic gastritis, pernicious anemia, systemic sclerosis, systemic lupus erythematous, and Sjögren's syndrome;

- A body mass index greater than or equal to 40 $\mathrm{kg} / \mathrm{m} 2$ has been associated with an increased prevalence of hypothyroidism;

- Women age 30 or older;

- Women treated with amiodarone, lithium;

- Recent (in the past 6 weeks) exposure to iodinated radiological contrast agents. ${ }^{7,22}$

\section{HYPOTHYREOSIS IN LATVIAN PREGNANT WOMEN}

Iodine content in urine was used in studies to select people with iodine deficiency, because urine contains $90 \%$ of the dietary iodine.

- Norm 100 to $300 \mathrm{mg} / \mathrm{L}$

- Light deficit from 50 to $99 \mathrm{mg} / \mathrm{L}$

- Moderate deficit of 20 to $49 \mathrm{mg} / \mathrm{L}$

- Severe deficiency $<20 \mathrm{mg} / \mathrm{L}^{21}$

Pregnant women urinary iodine levels should be between 150 and $249 \mathrm{mg} / \mathrm{L}$, during breastfeeding $\geq 100 \mu \mathrm{g} / \mathrm{l}$, because breast milk contains iodine. In Latvian study among pregnant women iodine deficiency was found. In this study, it was found that $81 \%$ of pregnant women receive less iodine than recommended and only $19 \%$ of pregnant women have sufficient iodine levels in the urine $(>150 \mathrm{mg} / \mathrm{L})^{23}$ 
To promote adequate iodine intake, ensure a varied diet, including foods that are natural sources of iodine, such as marine fish, legumes and vegetables as well as milk and dairy products. Iodised salt use is recommended for household. During pregnancy more than $500 \mathrm{mg}$ of iodine should be taken with a diet, because it can contribute to the development of foetal hypothyroidism. ${ }^{23-25}$

In 2014 was conducted retrograde study "Hypothyroidism and pregnancy process". The study aims to evaluate the effects of hypothyroidism on pregnancy and its outcome in P. Stradins Clinical University Hospital and "Riga Maternity Hospital" Ltd. in the period from 2010 to 2011. 160 histories of childbirth of pregnant women with hypothyroidism (Group 1) were summarised and included into hypothyroidism group and 308 histories of childbirth in control group (Group 2). Data were processed statistically using SPSS 20.0 and Excel 2010. The study and control groups were compared using $\mathrm{T}$ - test of two independent samples with a $95 \%$ confidence interval.

Preeclampsia incidence in hypothyroidism group is $6.9 \%$, and $2.6 \%$ in the control group. The incidence of preeclampsia statistically differs in both study groups $(\mathrm{P}$ $=0.02642$ ).

Comparing the two groups according to delivery type frequency in each of them, statistical difference was not observed (Table 3). Results of the study show that hypothyroidism does not affect the delivery type.

Table 3: Types of delivery.

\begin{tabular}{|lll|}
\hline & $1^{\text {st }}$ group & $2^{\text {nd }}$ group \\
\hline Vaginal delivery & $62.5 \%$ & $65.9 \%$ \\
\hline Planned caesarean section & $26.3 \%$ & $21.4 \%$ \\
\hline Emergency caesarean section & $11.3 \%$ & $12.6 \%$ \\
\hline
\end{tabular}

Literature data show an increased risk of postpartum haemorrhage. $^{26}$ Increased vaginal bleeding during childbirth is a blood loss of more than $500 \mathrm{ml}$, more than $1000 \mathrm{ml}$ during caesarean section. Hypothyroidism group enhanced postpartum haemorrhage occurred in $3.75 \%$ of cases, $3.89 \%$ of cases in the control group. $(\mathrm{P}=0.93624)$. The research results show that hypothyroidism does not affect postpartum bleeding.

Results of the study conducted in New Jersey show that hypothyroidism and autoimmune thyroid disease in euthyroid women are associated with preterm delivery. Incidence of preterm delivery decrease in thyroid antibody-positive women treated with levothyroxine. ${ }^{27}$ Our study results do not show statistically significant difference between the two study groups. In hypothyroidism group preterm birth has occurred in $8.75 \%$ of cases, and $8.44 \%$ in the control group $(\mathrm{P}=$ $0.9124)$.
Mothers with hypothyroidism are under the risk of foetus to be born with low birth weight. New Jersey study results show that there is a statistically significant difference between the control and hypothyroidism groups. In hypothyroidism group women are more likely to give birth to new-borns with low birth weight, but subclinical hypothyroidism does not affect birth weight. ${ }^{27}$ Latvian study shows that there is no statistically significant difference between the two study groups. The rate of new-borns with low birth weight in hypothyroidism group was $5.62 \%$ and $6.46 \%$ in the control group $(\mathrm{P}=0.71138)$.

Hypothyroidism affects foetal weight by altering the proliferative activity, apoptosis and vascularisation of the placenta. ${ }^{28}$ Study results also do not show statistically significant difference in foetal intrauterine growth between the two study groups.

In hypothyroidism group anaemia was experienced $18.1 \%$ of cases and $18.5 \%$ in the control group. Numerous factors can cause anaemia; it's well known that hypothyroidism can cause various types of anaemia, including microcytic, macrocytic, and normocytic anaemia. ${ }^{29}$ The survey data are not broad enough to be able to assess the reasons for the development of anaemia for pregnant women.

It should be noted that $92.5 \%$ of patients in hypothyroidism group were receiving L-thyroxin therapy during pregnancy.

\section{CONCLUSIONS}

- We Iodine deficiency can cause hypothyroidism development and has an important role in the course of pregnancy and foetal development;

- In case of hypothyroidism central nervous system development of foetus is incomplete as a result the child may be born with cretinism or reduced IQ;

- Normal level of iodine in the urine is 150 to 249 $\mathrm{mg} / \mathrm{L}$. In Latvia only $19 \%$ of pregnant women have enough iodine in the urine;

- Women with hypothyroidism have preeclampsia more often.

\section{Funding: No funding sources \\ Conflict of interest: None declared \\ Ethical approval: Not required}

\section{REFERENCES}

1. Frithjof C. Küpper, Lucy J. Carpenter, Catherine Leblanc. In vivo speciation studies and antioxidant properties of bromine in Laminaria digitatareinforce the significance of iodine accumulation for kelps. J Experiment Botany. 2013 Apr;64(10):2653-64. 
2. Robert M. Sargis. Thyroid gland overview. A major player in regulating your metabolism, 23 March 2015. Available at: http://www.endocrineweb.com/endocrinology/overvi ew-thyroid. Accessed 27 December 2015.

3. Louise Andersson. Embryonic origin and development of thyroid progenitor cells. In: Louise Andersson, eds. Abstract. Göteborg: University of Gothenburg; 2010: 10-15.

4. Philip E Zapanta. Embryology of the thyroid and parathyroids, 14 December 2014. Available at: http://emedicine.medscape.com/article/845125overview\#aw2aab6b2. Accessed 04 March 2015.

5. Donna D’Souza. Thyroid ima artery, 03 June 2014. Available at: http://radiopaedia.org/articles/thyroidea-ima-artery Accessed 26 February 2015.

6. Lewis Braverman, Linda Barbour. Pregnancy and thyroid disease, 23 February 2012. Available at: http://www.niddk.nih.gov/health-information/healthtopics/endocrine/pregnancy-and-thyroid-

disease/Pages/fact-sheet.aspx. Accessed 9 April 2015.

7. American Thyroid Association. Thyroid disease and pregnancy, 2012 Available at: http://www.thyroid.org/thyroid-disease-andpregnancy/. Accessed 11 April 2015.

8. University of Connecticut Health Center. Anatomy of the thyroid, 2015. Available at: http://fitsweb.uchc.edu/student/selectives/Luzietti/Th yroid_anatomy.htm. Accessed 04 March 2015.

9. Endocrine Surgery Centre. Anatomy of the thyroid gland. The blood supply, 2015. Available at: http://www.endocrinesurgeon.co.uk/index.php/anato my-of-the-thyroid-gland. Accessed 26 February 2015.

10. Dominique Dorion. Thyroid anatomy, 06 March 2013 Available at: http://reference.medscape.com/article/835535overview. Accessed 04 March 2015.

11. Françoise Miot, Corinne Dupuy, Jacques Dumont. Thyroid hormone synthesis and secretion, 26 December 2012. Available at: http://www.thyroidmanager.org/wp-

content/uploads/chapters/thyroid-hormone-synthesisand-secretion.pdf. Accessed 09 March 2015.

12. Evans JV. University of New England. Iodine and the thyroid gland. Mohair newsletter technical, September 1998. Volume 7. Available at: http://www.acga.org.au/goatnotes/C004.php. Accessed 17 April 2015.

13. The Endocrine Society. Smoking during pregnancy may impair thyroid function of mom and fetus, 17 January 2009. Available at: http://www.sciencedaily.com/releases/2009/01/0901 13090459.htm. Accessed 7 April 2015.

14. Kris Poppe, Brigitte Velkeniers, Daniel Glinoer. Thyroid disease and female reproduction. J Clin Endocrinol. 2000;66(3):309-21.
15. Dotun A. Ogunyemi, George T. Griffing. Autoimmune thyroid disease and pregnancy, 12 August 2014. Available at: http://emedicine.medscape.com/article/261913overview. Accessed 25 March 2015.

16. Kristīne Ducena. Vairogdziedzera slimības un grūtniecība, 2015. Available at: http://www.vairogdziedzeris.lv/index.php?page=vair ogdziedzeraslimibas. Accessed 8 April 2015.

17. Gene C. Ness, Tunekazu Takahashi. Thyroid hormones on amino acid and protein metabolism. I. Concentration and composition of free amino acids in blood plasma of the rat. Endocrinology. 1969 Dec;85(6):1166-71.

18. Juan Bernal. Thyroid hormones in brain development and function, 17 December 2012. Available at: http://www.thyroidmanager.org/chapter/thyroidhormones-in-brain-development-and-function/. Accessed 10 April 2015.

19. Chan S, Kilby MD. Thyroid hormone and central nervous system development. J Endocrinol. 2000;165:1-8.

20. Graham R. Williams. Actions of thyroid hormones in bone. Polish J Endocrinol. 2009;50(5):380-6.

21. Dace Rezeberga. Vitamins, supplements and women health, 08 February 2014. Available at: http://www.ginasoc.lv/uploads/content/wpcontent/uploads/Vitamini_Rezeberga14.pdf. Accessed 17 March 2015.

22. Dana Trentini. What every pregnant woman needs to know about hypothyroidism, 8 October 2012. Available at: http://hypothyroidmom.com/whatevery-pregnant-woman-needs-to-know-abouthypothyroidism/. Accessed 10 April 2015.

23. Dace Rezeberga. Recommendations for use of iodine Latvian, 15 January 2015. Available at: http://www.ginasoc.lv/uploads/content/6.D.Rezeberg a_Joda\%20rekomend\%C4\%81 cijas\%20Latvij\%C4\% 81.pd. Accessed 27 February 2015.

24. Serafino Fazio, Emiliano A. Palmeri, Gaetano Lombardi, Biondi B. Effects of thyroid hormone on the cardiovascular system. Recent Prog Horm Res. 2004;59:31-50.

25. Fryhofer A. Guidelines for thyroid disease in pregnancy: key points, 9 November 2011. Available at: http://www.medscape.com/viewarticle/752878. Accessed 15 April 2015.

26. Rodica Tudosa, Irina Horhoianu, Stela Mateescu. Maternal and fetal complications of the hypothyroidism-related pregnancy. J Maedica. 2010 Apr;5(2):116-23.

27. Alex Stagnaro-Green. Maternal thyroid disease and preterm delivery. J Clin Endocrinol Metab. 2009 Jan;94(1):21-5.

28. Juneo F. Silva, Paula N. Vidigal, Daniele D. Galvão. Fetal growth restriction in hypothyroidism is associated with changes in proliferative activity, apoptosis and vascularisation of the placenta. J Reprod Fertil Devel. 2012 Mar;24(7):923-31. 
29. Julie M. Gentile. Study looks at link between anemia and hypothyroidism, 2015. Available at: http://www.endocrineweb.com/professional/research -updates/thyroid-disorders/study-looks-link-betweenanemia-hypothyroidism. Accessed 19 March 2015.

30. Health Library. Thyroid disorders in women. Johns Hopkins medicine, 2015. Available at: http://www.hopkinsmedicine.org/healthlibrary/condit ions/endocrinology/thyroid_disorders_in_women_85 ,P00437/. Accessed 9 April 2015.

31. Solomon A. Berson, Rosalyn S. Yalow. The iodide trapping and binding functions of the thyroid. J Clin Invest. $1955 \mathrm{Feb} ; 34(2): 186-204$.
32. Bowen R. Mechanism of action and physiologic effects of thyroid hormones, July 2010. Available at: http://arbl.cvmbs.colostate.edu/hbooks/pathphys/end ocrine/thyroid/physio.html. Accessed 25 March 2015.

33. Douglas S. Ross. Patient information: hypothyroidism, 01 February 2015. Available at: http://www.uptodate.com/contents/hypothyroidismunderactive-thyroid-beyond-the-basics. Accessed 10 February 2015.

DOI: $10.18203 / 2320-1770 . i j r \operatorname{cog} 20150048$

Cite this article as: Abramova A, Galsone R.

Hypothyroidism and pregnancy. Situation in Latvia. Int J Reprod Contracept Obstet Gynecol 2015;4:540-6. 